\title{
Morphological characteristics of udders as selection criteria for improvement of mammary gland health and productivity of sheep. 1. Variability and genetic parameters of udder morphological traits
}

\author{
Krystyna M. Charon \\ Department of Genetics and Animal Breeding, Warsaw Agricultural University, \\ Przejazd 4, 05-840 Brwinów, Poland
}

(Received 23 February 1993; accepted 21 June 1993)

\begin{abstract}
The variability of morphological traits of sheep udders was studjed in the Polish Lowland, Polish Merino and Polish Highland sheep, which are bred for different purposes. Beside differences among brceds, intrabreed differences were found as regards the analyzed traits. The ewes of the breeds studied differed as regards udders shape and frequency of such anomalies as asymmetry of udder lobes or cxtra teats. The genetic parameters (heritability, repeatability and correlation) evaluated had moderate to high values, depending on the trait. This indicates a possibility of selection for improvement of udder health and shape and for increased productivity.
\end{abstract}

KEY WORDS: sheep, morphology of udders, genetic parameters

\section{INTRODUCTION}

The health of farm animals is one of the factors affecting production. Disease-related costs are estimated to run in the range of $10-20 \%$ of the total production value. In many countries, one of the major causes of financial losses in sheep breeding is mastitis. These losses are due to the death of or compulsory culling of sick ewes, veterinary costs, diminished milk yield and, in consequence, poorer growth or even mortality of lambs due to malnutrition. In Great Britain, where breeding is highly developed, these losses are estimated to reach 20 million pounds annually (M.L.C., 1988). Due to lack of effective methods of treatment and unavailability of vaccination, the use of breeding methods based on genetic

ISSN 1230-1388 @ Institute of Animal Physiology and Nutrition 
variability in resistance to mastitis seems to be the best way of limiting the frequency of this disease. These suggestions are supported by results of investigations on the fighting mastitis in cattle (Emanuelson, 1987; Madsen et al., 1987; Outteridge and Lee, 1988).

Long-term direct selection for resistance to mastitis would not only be difficult to carry out, but if the somatic cell count was used as the criterion, could weaken the immunological response of the organism (Emanuelson, 1987). In addition, selection based on this criterion could not be carried out earlier than during the second lactation (Madsen et al., 1987). For this reason, other ways of restricting mastitis are being looked for.

Many authors recommend indirect selection based on indicator traits. This type of selection is possible in young animals, in the first year of their breeding (Poutrel, 1983). Morphological chracteristics of udders and teats are genetically determined traits that can affect individual resistance to mastitis.

As a distinct correlation has been found between the mentioned traits and the occurrence of mastitis in cows (Madsen et al., 1987; Pander and Chopra, 1987; Outteridge and Lee, 1988), similar studies were undertaken in sheep. Their main objective was to assess the possibility of improving the health of the mammary gland of ewes as well as the rearing results of their offspring by using indirect selection based on the morphological characteristics of udders and teats.

The first stage of this study consisted of an analysis of the variability and estimation of the genetic parameters of morphological chracteristics of udders and teats.

\section{MATERIAL AND METHODS}

The morphological characteristics of udders were measured from 1983 to 1987 in primipara ewes from three breeds: Polish Merino (411 ewes), Polish Lowland sheep of the Żelazna variety (767 ewes) and the Polish Highland sheep (102 dams). The sheep used in this study represent the basic types of this species in Poland.

The morphological characteristics of udders and teats were measured by two persons at the peak of lactation, i.e. during weeks 7-8 after lambing for the dairy Highland sheep and during weeks 4-5 for the remaining breeds. This timing was based on data from literature (Mikuš, 1969; Labussière et al., 1981) and our own experience. The measurements were taken 6 to 9 hours after separating the ewe from the lamb.

The mean values of each measurement were used for a statistical analysis of each trait (according to the recommendations by Labussière et al., 1981). The following traits were measured: 
- length of the udder at its base, its depth and width (cm) using a special zoometrical rod,

- the longitudinal and transverse circumferences of the udder, distance between teats $(\mathrm{cm})$ - using a tape measure,

- the length and width of teats $(\mathrm{cm})$ - using a slide caliper,

- the angle of teat slanting $\left(\alpha_{1}\right.$ and $\left.\alpha_{\mathrm{p}}\right)\left(^{\circ}\right)$ - using a specially constructed protractor.

On the basis of results obtained and detailed observations of udders four types (round, box-shaped, pear-shaped and flat) and three teat shapes (conical, cylindrical, bottle-shaped) were distinguished. Cases of uneven development of udder lobes and the occurrence of extra teats were noted.

The arithmetic means $(\overline{\mathrm{x}})$ and variability coefficients $(\mathrm{V})$ of the measured traits of udders and teats were calculated for each of the studied breeds. The significance of the differences between breeds was determined using the F test and Duncan's test.

The genetic parameters (heritability, repeatability and correlations) of the analyzed morphological traits of sheep udders and teats were estimated.

The heritability of the characteristics of the udders and teats of the Polish Lowland and Merinos ewes as well as correlation between them were estimated by variance and covariance analysis (Harvey, 1987; mixed model 2) on groups of paternal half-sibs ( 54 and 48 groups, respectively) numbering on average 14.2 and 8.6 daughters, according to the following model:

$$
\mathrm{Y}_{\mathrm{ijk}}=\mu+\mathrm{A}_{\mathrm{i}}+\mathrm{b}_{\mathrm{j}}+\mathrm{e}_{\mathrm{ijk}}
$$

where:

$Y_{i j k}-$ the value of the trait for individual $k$, in year $i$, after sire $j$,

$\mu$ - general mean,

$A_{i}-$ fixed effect of the year of study $(i=1 \ldots 6$ for Polish Lowland ewes, $i=1 \ldots 5$ for Merino ewes),

$b_{j} \quad-$ random effect of sire genotype $(j=1 \ldots 54$ for Polish Lowland ewes, $\mathrm{j}=1 \ldots 48$ for Merino ewes),

$\mathrm{e}_{\mathrm{ijk}}$ - error.

The effect of factors not included in the model was incorporated into error variability.

Due to the small size of the Highland sheep herd the genetic parameters were not calculated for this breed.

The repeatability of morphological traits of udders was evaluated by the regression of 2nd and 3rd on 1st lactation, based on the measurements taken between 1987-1989 for Polish Lowland ewes only. In all, 543 observations were 
made of the traits studied (189 ewes - in 1st, 181 - in 2 nd and 173 - in 3rd lactation).

The standard error of the coefficient of repeatability was calculated using the formula given by Turner and Young (1969):

where:

$$
\sigma_{\mathrm{t}}=\frac{(1-\mathrm{t})[1+(\mathrm{k}-1) \mathrm{t}]}{[1 / 2 \mathrm{k}(\mathrm{k}-1)(\mathrm{n}-1)]^{1 / 2}}
$$

$\sigma_{t}-$ standard error of intraclass correlation,

$t$ coefficient of intraclass correlation,

$\mathrm{n}$ - number of animals,

$\mathrm{k}$ - number of observations of a trait per animal.

\section{RESULTS AND DISCUSSION}

The mean values and variability coefficient of morphological traits of ewe udders are presented in Table 1 . The greatest udder length and width was

TABLE 1

Mean value and variability index [\%] of udder morphological traits of investigated sheep

\begin{tabular}{|c|c|c|c|c|c|c|}
\hline \multirow{2}{*}{ Traits } & \multicolumn{2}{|c|}{ Polish Lowland } & \multicolumn{2}{|c|}{ Polish Merino } & \multirow{2}{*}{$\frac{\text { Polish }}{\overline{\bar{x}}}$} & \multirow{2}{*}{$\frac{\text { Mountain }}{V[\%]}$} \\
\hline & $\overline{\mathrm{x}}$ & $\mathrm{V}[\%]$ & $\overline{\mathrm{x}}$ & $\mathrm{V}[\%]$ & & \\
\hline Udder length & 13.93 & 9.02 & 12.65 & 10.10 & 11.49 & 14.88 \\
\hline$" \quad$ width & 13.91 & 7.87 & 12.58 & 10.61 & 11.32 & 11.03 \\
\hline$" \quad$ depth & 12.59 & 12.37 & 11.68 & 11.31 & 10.44 & 12.01 \\
\hline$" \quad$ trans. cir. & 28.12 & 10.99 & 26.59 & 12.40 & 22.46 & 10.44 \\
\hline$" \quad$ longit. cir. & 24.90 & 9.98 & 22.39 & 10.14 & 20.66 & 12.74 \\
\hline \multicolumn{7}{|l|}{ Distance between } \\
\hline$"$ teats & 14.03 & 11.23 & 11.30 & 14.28 & 10.35 & 13.88 \\
\hline Teat angle (left) & 55.04 & 17.76 & $51.50^{\mathrm{a}}$ & 17.79 & $49.86^{\mathrm{a}}$ & 23.72 \\
\hline$" \quad " \quad$ (right) & 57.64 & 15.86 & 52.32 & 17.11 & 44.87 & 20.93 \\
\hline$"$ length (left) & $2.57^{\mathrm{b}}$ & 13.46 & $2.53^{\mathrm{b}}$ & 13.70 & 2.24 & 20.29 \\
\hline$" \quad " \quad$ (right) & 2.55 & 13.57 & 2.68 & 13.46 & 2.18 & 21.84 \\
\hline , diam. (left) & 1.33 & 12.57 & 1.45 & 14.46 & 1.24 & 20.21 \\
\hline$" \quad, \quad$ (right) & 1.34 & 12.83 & 1.49 & 15.85 & 1.26 & 17.01 \\
\hline
\end{tabular}

$\mathrm{a}, \mathrm{b}-$ nonsignificant differences between particular breeds

observed in the Polish Lowland ewes $(13.93 \mathrm{~cm}$ and $13.91 \mathrm{~cm}$, respectively). These traits were also characterized by the smallest variance $(9.02 \%$ and $7.87 \%)$. Similar tendencies were noted in the longitudinal circumference $(24.90 \mathrm{~cm}$, $\mathrm{V}=9.98 \%$ ) which is, to a certain degree, dependent on udder length and distance 
between teats, which is in turn partly determined by udder width. The Polish Lowland ewes showed the highest values and uniformity of these traits.

The Polish Highland ewes were characterized by the smallest dimensions of both udders and teats, but also had the highest variability of most of the studied traits. The Merino ewes generally had medium sized udders but their teats were the widest $(1.45 \mathrm{~cm}$ left and $1.49 \mathrm{~cm}$ right).

The differences in the values of morphological traits of udders and teats found between the breeds studied were, with a few exceptions, statistically highly significant (Table $1 ; \mathrm{F}$ test at $\mathrm{P} \leqslant 0.01$ ).

The diversity observed in udder morphology between breeds may result from different uses of the ewes of the studied breeds. This is supported by other authors (Labussière et al., 1981; Labussière, 1988; Gallego et al., 1983; Mavrogenis et al., 1985).

Although certain udder traits were found to be characteristic for each breed, a variability within breeds was also observed, as indicated by variability coefficients (Table 1). Teat morphological traits of the studied breeds were characterized by a higher variability than the udder traits.

Significant differences in udder shape were observed among breeds (Table 2). The Lowland and Highland ewes usually had box-shaped udders. The udders of Merino ewes were predominantly round. The frequency of teats of particular shapes was similar in the breeds studied, with conical teats prevailing.

TABLE 2

Frequency of occurrence [\%] of the defined shape of udder and teats in the investigated breeds

\begin{tabular}{|c|c|c|c|c|c|c|c|}
\hline \multirow{2}{*}{ Breed } & \multicolumn{4}{|c|}{ Shape of udder } & \multicolumn{3}{|c|}{ Shape of teat } \\
\hline & $\begin{array}{l}\text { spheri- } \\
\text { cal }\end{array}$ & $\begin{array}{l}\text { box- } \\
\text { shaped }\end{array}$ & $\begin{array}{l}\text { pcar- } \\
\text { shaped }\end{array}$ & flat & conical & $\begin{array}{l}\text { cylin- } \\
\text { drical }\end{array}$ & $\begin{array}{l}\text { bottle- } \\
\text { shaped }\end{array}$ \\
\hline Polish & & & & & & & \\
\hline $\begin{array}{l}\text { Lowland } \\
\text { Polish }\end{array}$ & 11.40 & 71.88 & 8.21 & 8.51 & 80.58 & 11.94 & 7.48 \\
\hline $\begin{array}{l}\text { Merino } \\
\text { Polish }\end{array}$ & 51.66 & 36.57 & 11.00 & 0.77 & 76.63 & 15.83 & 7.54 \\
\hline Mountain & 14.92 & 73.13 & 2.99 & 8.96 & 79.22 & 14.29 & 6.49 \\
\hline
\end{tabular}

One of the udder abnormalities which may be of practical importance, especially in prolific sheep breeds, is the occurrence of extra, functional teats. This trait is highly heritable, probably determined by a single dominant gene (Cardell, 1987; Davis, 1988) and occurs with varying frequency in many breeds (Maijala and Kyle, 1988; Livestock Farming, 1987; Davis, 1988). Extra teats were also observed in the present study (Table 3 ) and their size varied widely. The potential importance of this trait for breeding is exemplified by the fact that a breed of 
TABLE 3

Frequency of occurrence of additional teats [\%]

\begin{tabular}{lccc}
\hline Teat & $\begin{array}{c}\text { Polish Lowland } \\
\text { sheep }\end{array}$ & $\begin{array}{c}\text { Polish Merino } \\
\text { sheep }\end{array}$ & $\begin{array}{c}\text { Polish Mountain } \\
\text { sheep }\end{array}$ \\
\hline Left & 2.0 & 4.4 & 5.4 \\
Right & 0.8 & 0.9 & 2.2 \\
Left \& right & 7.6 & 8.4 & 14.1 \\
\hline
\end{tabular}

sheep with four functional teats has been developed in New Zealand (Cardell, 1987). Researchers from Liverpool University are planning to make use of this characteristic in order to improve lamb rearing results in the Cambridge prolific breed (higher milk yield in dams, the ability to nurse more than two lambs) (Livestock Farming, 1987).

When analyzing the morphology of udders one cannot ignore the numerous abnormalities. They are an important reason for culling ewes (Madel, 1981) and, regardless of the purpose of breeding sheep, they play an important role in the nursing of lams and milk yield of dams. Data on the observed frequency of udders with asymmetric lobes is presented in Table 4 . Merino ewes were characterized by

TABLE 4

Frequency of occurrence of asymmetric udder [\%]

\begin{tabular}{lccc}
\hline \multicolumn{1}{c}{ Asymmetry } & $\begin{array}{c}\text { Polish Lowland } \\
\text { sheep }\end{array}$ & $\begin{array}{c}\text { Polish Merino } \\
\text { sheep }\end{array}$ & $\begin{array}{c}\text { Polish Mountain } \\
\text { sheep }\end{array}$ \\
\hline Left half bigger & 4.4 & 4.4 & 3.2 \\
Right half bigger & 4.5 & 5.6 & 4.3 \\
\hline Total & 8.9 & 10.0 & 7.6 \\
\hline
\end{tabular}

the highest frequency of asymmetric udders $(10.0 \%)$, Highland ewes by the lowest $(7.6 \%)$. The studies of some authors (Kirk et al., 1980) have shown a significant correlation between these types of abnormalities in ewes udder morphology and the mortality of their lambs.

The heritability coefficients for the morphological traits of udders and teats for Polish Lowland and Merino ewes are shown in Table 5. The morphological traits of Lowland ewe udders were characterized by a higher heritability than those of Merino ewes. These differences can, however, arise from the smaller number of studied Merino ewes, and therefore the smaller number of half-sib groups.

The udder depth showed the highest heritability among the traits recorded for Lowland ewes $(0.43 \pm 0.12)$. A similar value $(0.48 \pm 0.11)$ for heritability of udder 
TABLE 5

Heritability of udder morphological traits of Polish Lowland sheep and Polish Merino

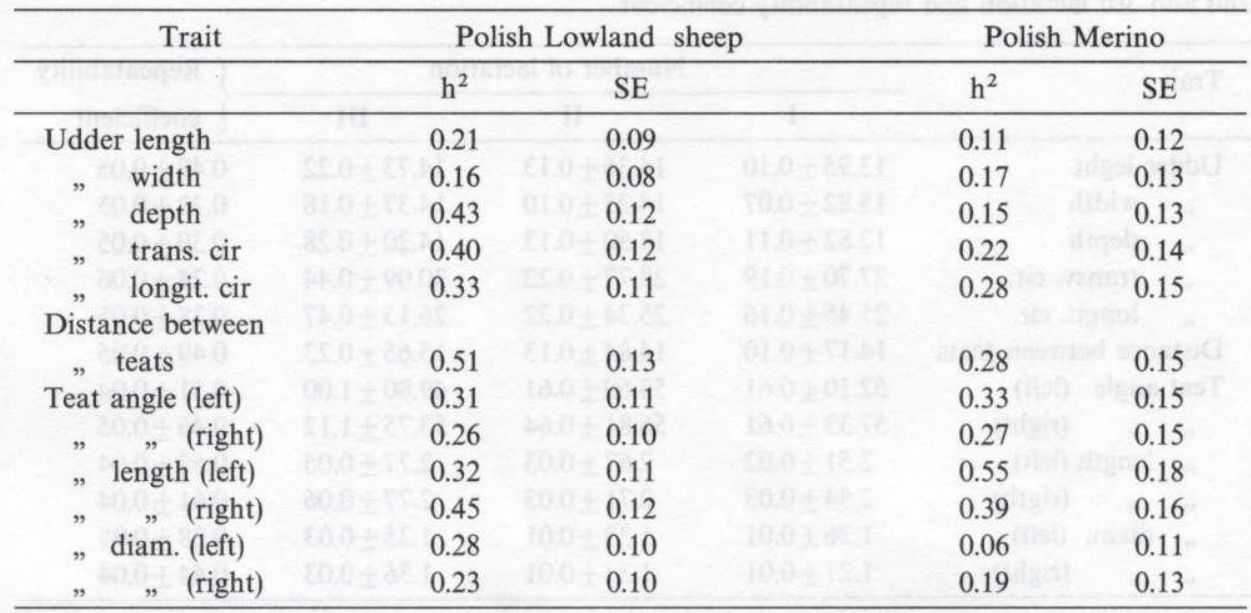

depth was obtained for Chios dairy sheep by Mavrogenis et al. (1985). In the opinion of those authors, in addition to depth, udder length and circumference are the best traits describing udder type and capacity.

The highest heritability of such traits as transverse and longitudinal circumference $(0.22 \pm 0.14$ and $0.28 \pm 0.15$, respectively) was found in the Merino ewes.

Among traits recorded for teats the highest values was found in the ewes of both breeds for teat length (Table 5). The remaining teat traits (width and slant) were characterized by a low heritability. A high degree of genetic determination $\left(\mathrm{h}^{2}\right.$ in the range of 0.6 to 0.8 ) was also found for teat length by other authors (Mikuš, 1972; Mavrogenis et al., 1985) in Chios and Cygaja ewes.

The heritability of the morphological traits of udders and teats, assessed by this and other authors indicate a possibility of selecting for improvement of these traits. This type of selection is recommended for cows (Ovesen, 1972; Batra and McAllister, 1984) as well as sheep (Gootwine et al., 1980; Mavrogenis et al., 1985). The important problem is at what of the animal life should this selection be conducted.

Udder and teat shape and size change with the age of the ewe. The greatest differences in the range of the studied parameters occur between the first, second and third lactation, which is reflected in the repeatability of the traits (Gootwine et al., 1980; Purroy Unanua and Diaz, 1983; Mavrogenis et al., 1985).

In the studied herd of Polish Lowland ewes, a constant, although small, growth in mean values of most of the analyzed udder and teat characteristics was 
TABLE 6

Average value of the morphological traits of udder and teats $(\overline{\mathrm{x}} \pm \mathrm{SE})$ of Polish Lowland sheep in 1st, 2nd and 3rd lactation and repeatability coefficient

\begin{tabular}{|c|c|c|c|c|}
\hline \multirow{2}{*}{ Trait } & \multicolumn{3}{|c|}{ Number of lactation } & \multirow{2}{*}{$\begin{array}{l}\text { Repeatability } \\
\text { coefficient }\end{array}$} \\
\hline & I & II & III & \\
\hline Udder leght & $13.95 \pm 0.10$ & $14.36 \pm 0.13$ & $14.73 \pm 0.22$ & $0.48 \pm 0.05$ \\
\hline " width & $13.82 \pm 0.07$ & $14.25 \pm 0.10$ & $14.37 \pm 0.18$ & $0.32 \pm 0.05$ \\
\hline " depth & $12.82 \pm 0.11$ & $13.50 \pm 0.13$ & $14.20 \pm 0.28$ & $0.30 \pm 0.05$ \\
\hline$" \quad$ transv. cir. & $27.70 \pm 0.19$ & $28.77 \pm 0.22$ & $30.09 \pm 0.44$ & $0.24 \pm 0.06$ \\
\hline " longit. cir. & $25.45 \pm 0.16$ & $25.34 \pm 0.22$ & $26.13 \pm 0.47$ & $0.38 \pm 0.05$ \\
\hline Distance between teats & $14.17 \pm 0.10$ & $14.84 \pm 0.13$ & $15.65 \pm 0.23$ & $0.49 \pm 0.05$ \\
\hline Teat angle (left) & $52.10 \pm 0.61$ & $53.69 \pm 0.61$ & $49.80 \pm 1.00$ & $0.51 \pm 0.04$ \\
\hline$" \quad, \quad$ (right) & $57.33 \pm 0.61$ & $56.81 \pm 0.64$ & $53.75 \pm 1.12$ & $0.46 \pm 0.05$ \\
\hline " length (left) & $2.51 \pm 0.02$ & $2.67 \pm 0.03$ & $2.77 \pm 0.05$ & $0.52 \pm 0.04$ \\
\hline ",$\quad$ (rigth) & $2.54 \pm 0.03$ & $2.71 \pm 0.03$ & $2.77 \pm 0.06$ & $0.61 \pm 0.04$ \\
\hline " diam. (left) & $1.26 \pm 0.01$ & $1.33 \pm 0.01$ & $1.35 \pm 0.03$ & $0.38 \pm 0.05$ \\
\hline$, \quad, \quad$ (right) & $1.27 \pm 0.01$ & $1.34 \pm 0.01$ & $1.36 \pm 0.03$ & $0.44 \pm 0.04$ \\
\hline
\end{tabular}

found from the first to third lactation (Table 6). Only teat slant decreased with increasing age of the ewes. These changes were confirmed by the value of the repeatability coefficient (Table 6). The lowest values of this parameter were characteristic for udder depth $(0.30 \pm 0.05)$ and transverse circumference $(0.24 \pm 0.06)$, the highest for length $(0.48 \pm 0.05)$ and longitudinal circumference $(0.38 \pm 0.05)$.

Increases in udder circumference and depth among the first three lactations have also been observed in other breeds such as Karagouniko (Hatziminaoglou et al., 1983) and Chios (Mavrogenis et al., 1985).

Knowledge of the relationships among traits is of great importance for the genetic improvement of a herd. The value of the phenotypic and genetic correlation coefficients obtained in this study for morphological traits of the mammary glands of Polish Lowland and Merino sheep are presented in Tables 7 and 8. High, positive phenotypic and genetic correlations among all the morphological udder traits were found in ewes of both analyzed breeds. In the Polish Lowland dams only udder length showed a low degree of correlation with its width $\left(\mathrm{r}_{\mathrm{g}}=0.26 \pm 0.32, \mathrm{r}_{\mathrm{p}}=0.54\right)$.

The genetic correlation coefficient in Merino ewes was high between udder length and depth as well as transverse and longitudinal circumferences $(0.53 \pm 0.51,0.65 \pm 0.38$ and $0.96 \pm 0.22$, respectively). The depth of Merino ewe udders was highly correlated with the transverse $\left(r_{g}=0.54 \pm 0.37\right)$ and longitudinal $\left(\mathrm{r}_{\mathrm{g}}=0.85 \pm 0.24\right)$ circumferences of this gland.

Very strong genetic correlations were found among the traits of teats in both Lowland and Merino ewes (Tables 7 and 8). A similar phenomenon was observed 


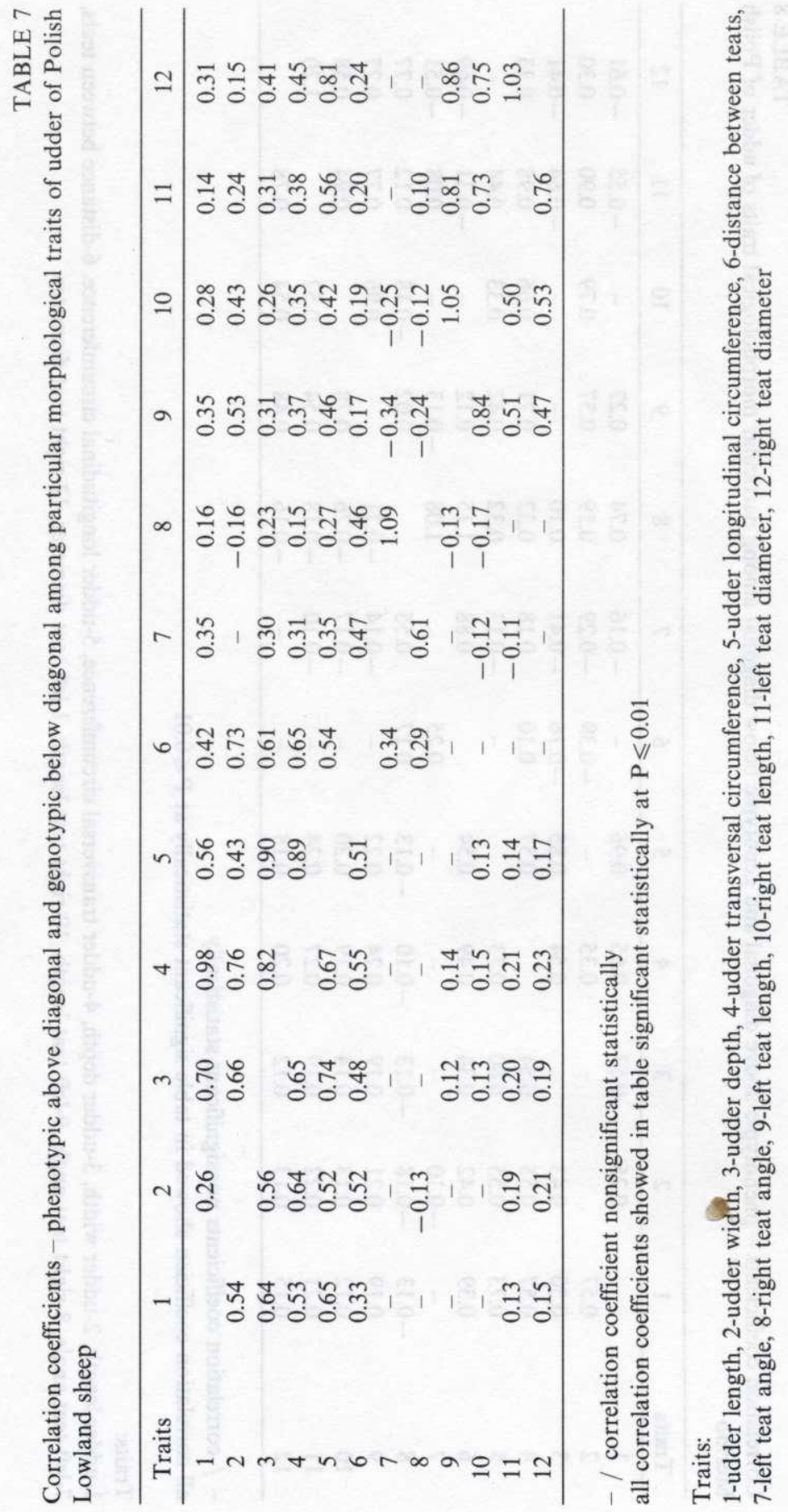




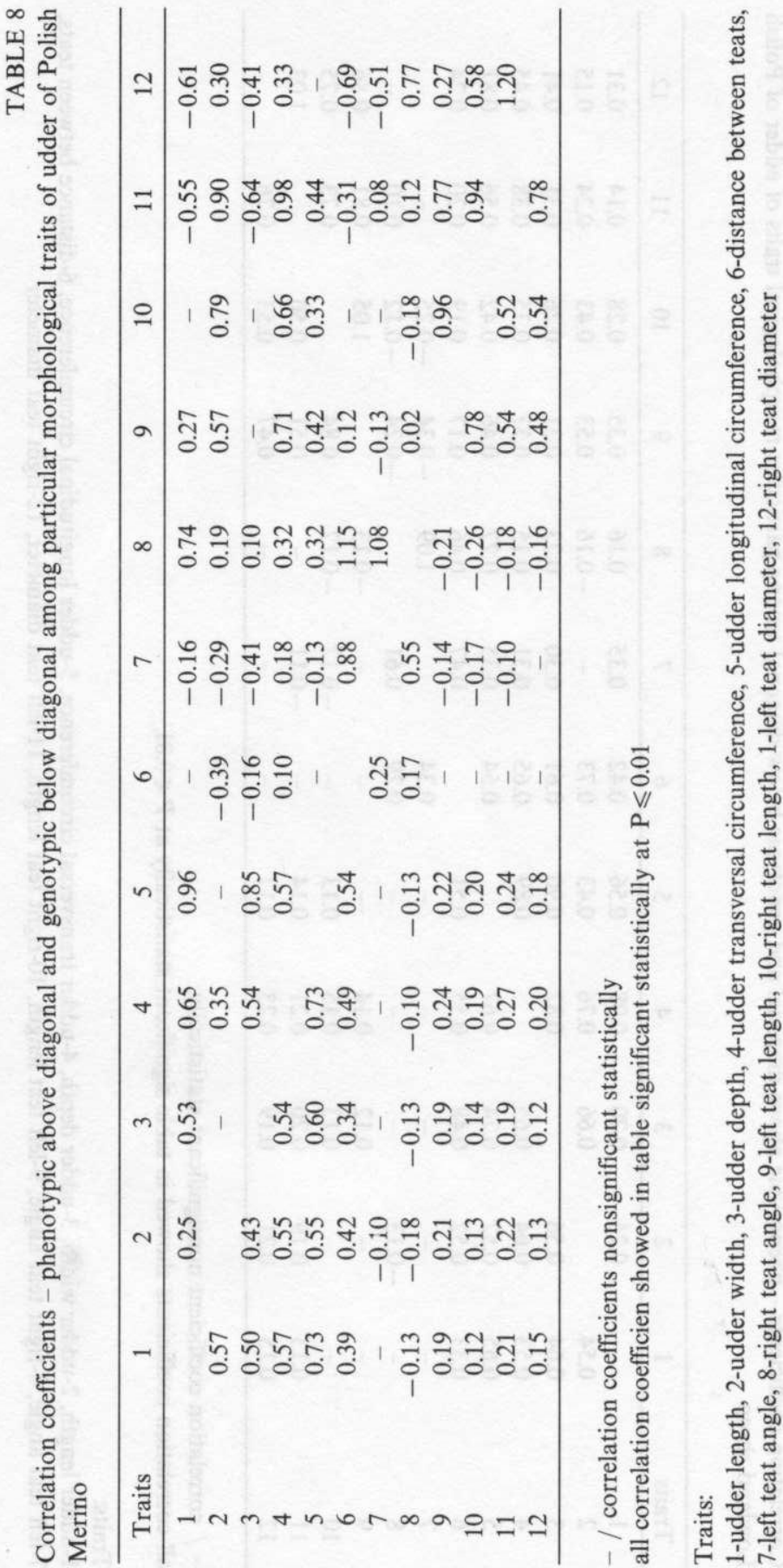


by Ovesen (1972) in primipara dairy cows. That author suggested that the dimenshions of only one teat can be taken as a selection criterion.

The results obtained in this study on the relationship among morphological traits of udders and teats correspond with result reported by other authors (Labussière et al., 1981; Casu et al., 1983; Fernandez et al., 1983; Kanazovicky et al., 1983; Mavrogenis et al., 1985; Labussière, 1988) for ewes from various breeds and justifies carrying out selection for chosen traits which assures improvement of the remaining traits (a correlated response to selection).

\section{CONCLUSIONS}

1. Four types of udder shape (round, box-shaped, pear-shaped and flat) and three types of teat shape (conical, cylindrical and bottle-shaped, were found in ewes of the studied breeds.

2. The correlations found among the morphological traits of udders and teats make it possible to select for some of these traits and obtain improvement in others.

The relatively high values of the coefficients of heritability and repeatability of the analyzed traits ensure a successful selection.

\section{LITERATURE}

Batra T.R., McAllister J., 1984. Relationships among udder measurements, milking speed, milk yield and CMT scores in young dairy cows. Can. J. Anim. Sci. 64, 807-815

Casu S., Carta R., Ruda G., 1983. Morphologie de la mamelle et aptitude à la traite mecanique de la brebis Sarde. III Symp. on Machine Milining of Small Ruminants, Valiadolid, Spain, $592-603$

Cardell K., 1987. Breeding for four teats. The Sheep Farmer, 5/6, 28-29

Davis D.A.R., 1988. Breeding sheep with four teats in Devon, England. Fin. J. Agric. Sci. 60, 620-621

Emanuelson V., 1987. Genetic studies on the epidemiology of mastitis in dairy cattle. Report 73, Swedish Univ. Agric. Sci., Uppsala, 1-17

Fernandez N., Arranz J., Caja G., Torres A., Gallego L., 1983. Aptitud al ordeno mecanico de ovejas de raza Manchega. I. Biometria corporal caracteristicas morfologicas de la ubre, caida de pezoneras y cria de corderos. III Symp. on Machine Milking of Small Ruminants, Valladolid, Spain, 653-666

Gallego L., Caja G., Torres A., 1983. Estudio de la tipologia y caracteristicas morfologicas de las ubres de ovejas de raza Manchega durante la lactation. III Symp. on Machine Milking of Small Ruminants. Valladolid, Spain, 111-116

Gootwine E., Alef B., Gadeesh S., 1980. Udder conformation and its heritability in the Assaf (Awassi $\times$ East Friesian) cross of dairy sheep in Israel. Ann. Gèn. Sèl. Anim. 12, 9-13

Harvey W.R., 1987. User's Guide for LSMLMW Mixed Model Least-Squares and Maximum Likelihood Computer Program. Monogr., Ohio Univ.

Hatziminaoglou J., Zervas N., Sinapis E., Hatziminaouglou P., 1983. Aptitude à la traite mecanique des brebis de race Karagouniko (Gréce). Comite International pour la Traite des Petits Ruminants. Sous-Reseau Ovin Mediterraneen de la FAO (Project M4), 1-16

Kirk J.H., Huffman E.M., Anderson B.C., 1980. Mastitis and udder abnormalities as related to neonatal lamb mortality in shed-lambed range ewes. J. Anim. Sci. 50, 610-616 
Knazovicky F., Bednik J., Gazarek J., 1983. Estudio de las caracteristicas morfologicas de la ubre de las ovejas Tsigai con relacion al ordeno mecanico. III Symp. on Machine Milking of Small Ruminants, Valladolid, Spain, 140-148

Labussière J., 1988. Review of physiological and anatomical factors influencing the milking ability of ewes and the organization of milking. Livest. Prod. Sci. 18, 253-274

Labussière J., Dotchewski D., Combaud J.F., 1981. Caracteristiques morphologiques de la mamelle des brebis Lacaune. Méthologie pour l'obtention des données. Relations avec l'aptitude a la traite. Ann. Zootech., 30, 115-136

Livestock Farming, 1987. Breeding for four teats, 7, 23

Madel A.J., 1981. Observations on the mammary glands of culled ewes at the time of slaughter. Vet. Rec. $109,362-363$

Madsen P., Nielsen Sv.M., Dam Rasmussen M., Klastrup O., Jensen N.E., Thode Jensen, Schmidt Madsen P., Larsen B., Hyldgaard.Jensen J., 1987. Investigations on genetic resistance to bovine mastitis. Report 621, Nat. Inst. of Anim. Sci., Denmark, 1-227

Maijala K., Kyle B., 1988. Possibilities of developing sheep which suckle from several teats. Fin. J. Agric. Sci. 60, 608-619

Mavrogenis A.P. Papachristoforou Chr., Lysandrides Ph., Roushias A., 1985. Environmental and genetic factor affecting udder characteristics and milk production in Chios sheep. $36 \mathrm{Ann}$. Meet. EAAP, Kallithea, Halkidiki, Greece, 186-187

Mikuš M., 1969. Metodiky. Zistovanie a hodnotenie morfologickych a funkenych vlastnosti vemena u oviec. Československa Polnohospodàrska Akadèmia, Ustav Vedecko-Technickych Informacji, 17, 1+11

Mikuš M., 1972: Dedivost funkenych vlastnosti vemena u Cigajok. Ved. Pr. Vysk. Ust. Ovc. v Trencine, 5, 97-104

M.L.C., 1988. Sheep Yearbook. Mastitis in ewes., Milton Keynes, 39-40

Outteridge P.M., Lee C.S., 1988. The defence mechanism of the mammary gland of domestic ruminants. Prog. Vet. Microbiol. Immun. 4, 165-196

Ovesen E., 1972. Milking ability in relation to size and shape of teats. Anim. Prod. 15, 251-257

Pander B.L., Chopra S.C., 1987. Incidence of subclinical mastitis at implantation to production traits and udder and teat phenotype in cross-bred dairy cattle. Indian J. Dairy Sci. 40, 363-364

Poutrel B., 1983. Les mammites de la chèvre et de la brebis. Dossiers de l'Elevage 5, 37-45

Purroy Unanua A., Diaz. M.J.L., 1983. Caracteristicas de ordeno de la oveja Churra. Production y composition de leche: morfologia de la ubre y cinetica de emision de leche. III Symp. on Machine Milking of Small Ruminants, Valladolid, Spain, 568-582

Turner H.W., Young S.S.Y., 1969. Quantitative genetics in sheep breeding. South Melbourne, 1-81

\section{STRESZCZENIE}

Cechy morfologiczne wymion jako kryteria selekcji w celu poprawy zdrowotnosci gruczołu mlekowego i produkcyjności owiec. 1. Zmienność i parametry genetyczne cech budowy morfologicznej wymion

Analizowano zmienność cech budowy morfologicznej wymienia owiec trzech ras - polska owca nizinna, merynos polski i polska owca górska różniących się kierunkiem użytkowania. Stwierdzono różnice nie tylko międzyrasowe ale $\mathrm{i}$ wewnątrzrasowe $\mathrm{w}$ zakresie analizowanych cech. Owce badanych ras różnily się kształtem wymion oraz częstością występowania takich anomalii, jak asymetria płatów wymienia czy występowanie strzyków dodatkowych. Oszacowane parametry genetyczne (odziedziczalność, powtarzalność i korelacje) miały wartości średnie do wysokich, zależnie od cechy. Sugeruje to możliwość prowadzenia pracy hodowlanej w celu poprawy budowy i zdrowotności wymion oraz wyników produkcyjnych owiec. 